\title{
Victorian Voting: The Origins of Party Orientation and Class Alignment
}

\author{
Torun Dewan $^{\dagger} \quad$ Jaakko Meriläinen ${ }^{\ddagger} \quad$ Janne Tukiainen ${ }^{\S}$
}

August 26, 2019

\footnotetext{
${ }^{*}$ For helpful comments and discussions, we thank three anonymous referees and the editors of this journal; Gary Cox, Miriam Golden, Chris Kam, Tuomas Pekkarinen, Torsten Persson, Daniel Rubenson, Jim Snyder, and Till Weber; seminar audiences at Harvard, HECER, IIES-Stockholm University, University of Helsinki, VATT, Nuffield College Oxford, Stanford, and Yale; and participants of LSE Historical Political Economy Workshop and at the EPSA meetings in Milan.

${ }^{\dagger}$ Department of Government, London School of Economics and Political Science, Houghton Street, London WC2A 2AE, United Kingdom, T.Dewan@lse.ac.uk, Tel $+44(0) 2079556406$.

łCenter for Economic Research, Instituto Tecnológico Autónomo de México, Col. Héroes de Padierna, Del. Magdalena Contreras, C.P. 10700 México, D.F., Mexico, jaakko.merilainen@itam.mx, Tel +525582327639; Institute for International Economic Studies, Stockholm University, SE-10691 Stockholm, Sweden.

\$Corresponding author. VATT Institute for Economic Research, Arkadiankatu 7, Helsinki FI-00101, janne.tukiainen@vatt.fi, Tel +358295519451; Department of Government, London School of Economics and Political Science, Houghton Street, London WC2A 2AE, United Kingdom; Department of Economics, Turku School of Economics, Rehtorinpellonkatu 3, FI-20014 University of Turku.
} 


\begin{abstract}
Much of what we know about the alignment of voters with parties comes from mass surveys of the electorate in the postwar period or from aggregate electoral data. Using individual elector level panel data from 19th-century United Kingdom poll books, we reassess the development of a party-centred electorate. We show that (i) the electorate was party-centred by the time of the extension of the franchise in 1867; (ii) a decline in candidate-centred voting is largely attributable to changes in the behaviour of the working class; and (iii) the enfranchised working class aligned with the Liberal left. This early alignment of the working class with the left cannot entirely be explained by a decrease in vote buying. The evidence suggests instead that the alignment was based on the programmatic appeal of the Liberals. We argue that these facts can plausibly explain the subsequent development of the party system.
\end{abstract}

Harvard Dataverse DOI: https ://doi.org/10.7910/DVN/AH2PEI.

Keywords: Candidate-vs-party-oriented voting, party development, partisan alignment Word Count: 9,997 


\section{Introduction}

A central element in the political development of a country is the connection between voters and those who represent them. This connection can take different forms: it may exist due to patronage, vote buying, or coercion; be based on the personal characteristics or beliefs of the candidate; or arise due to an affiliation between voters and particular parties. An important distinction is that between candidate-centred systems and partyoriented ones. In the latter, voters are loyal to their preferred party and cast their votes without regard to the personal characteristics, beliefs, or favours offered by candidates.

These patterns of development vary across countries and over time. In the United States parties that emerged as loose coalitions or caucuses of legislators (Aldrich 1995), developed into the well-oiled machines of the early nineteenth century that delivered patronage. As these weakened in the latter part of the century, due in part to civil service reform as well as the introduction of primary elections, a candidate centred system emerged (Folke, Hirano, and Snyder 2011). Duverger (1959, p. 28) noted a different pattern of party development in European parliamentary democracies where "first there is the creation of parliamentary groups, then the appearance of electoral committees, and finally the establishment of a permanent connection between these two elements." According to Duverger the key factors that lead to the emergence of such party-oriented systems were the extension of popular suffrage, the role of parliamentary prerogatives, and (later, and in some countries) the emergence of organized mass parties on the left who connected with working class voters on the basis of ideology. Indeed, recent work by Hidalgo (2012) shows that extension of the franchise in Brazil is causally related to the votes shares of parties with clear ideological profiles. Moreover, Fujiwara and Wantchekon (2013) show that party-oriented systems, based on parties with clear ideological programmes, can have positive welfare effects.

It is important then to understand when and why such parties emerge and what are the institutional (and other) determinants. Much of what we know about the alignment 
of voters with parties in the developed world comes from mass surveys of the electorate, developed and implemented in the postwar period, or from aggregate electoral data. The problem with the former, is that it limits our understanding to changes in party alignment that occurred after the development of techniques designed to measure such change. The problem with the latter, is the commonly understood problem of ecological inference: we can not be sure how aggregate patterns observed in the data relate to individual-level behaviour.

In this paper we provide a resolution to this problem by analysing historical individual-level data on actual voting behaviour. Before the establishment of the Ballot Act in 1872, voting in Parliamentary elections in the United Kingdom was public. Often the name of each voter and how they voted was recorded in poll books. In addition, these poll books sometimes provided information, such as electors' addresses and occupations. Due to recent work by historians, some poll books have become available electronically. Here we construct voter level panel data from a sample of 19th century borough constituencies. Analysing these remarkable data, using appropriate estimation techniques, provides a unique micro view of the emerging relationship between voters and political parties in Victorian England.

Our analysis of these data enhances the understanding of party development in several ways. First, we provide new evidence on the timing of emergence of a party-oriented electorate in the United Kingdom. Our results corroborate those in the seminal work by Cox $(1984,1986,1987)$ that are based on aggregate data from UK elections and show that cohesive parties with close links to the electorate preceded the major (late) Victorian franchise reforms and coincided with a period during which the executive took control of prerogative. Second, our main and novel contribution uses voter-level data to understand the driving forces behind partisan alignment. The analysis of our data reveals that partisan alignment was largely due to the behaviour of 
the skilled working classes, who had been enfranchised in 1832. Third, we show that this group aligned with the then left Liberal Party.

We also shed light on mechanisms that might explain these patterns in our data, showing that the increased partisan attachment amongst the electorate can largely be attributed to a decrease in vote buying or clientelism. We find, however, that working class voters aligned with the Liberal Party for reasons other than patronage which, as shown by Stokes et al. (2013) and Camp, Dixit, and Stokes (2014), was in decline during this period. In fact, our data is consistent with claims made by Stokes and coauthors and by Cox that the alignment of the working class had more to do with the programmatic appeal of the Liberal Party.

These results and what they tell us about party alignment in Victorian England have broad relevance. To our knowledge ours is the first analysis of individual-level data which confirms that class alignment occurred prior to the enfranchisement of the (unskilled) working classes and several decades before the development of mass parties that organised sections of the electorate. In fact the pre-1867 Liberal Party under Palmerston was a quintessential "cadre party" as defined by Duverger. It was a loose amalgamation of different parliamentary factions who voted together in parliament and stood on a common legislative programme, albeit a sparse one. Critically it had no organisational basis within the electorate. The central lesson then is that class alignment occurred prior to the development of organised mass parties.

A further lesson involves the dynamic relationship between party support and programmatic development. That working class voters should align with the left party at such an early point in Britain's political development might seem surprising. Palmerston's Liberal Party preceded the period of Progressive Liberalism and can not be compared to Gladstone's Liberal Party in terms of its programme or legislative achievements. Nor, of course, was it a party of the workers in the sense that the Labour Party of the interwar years was to become. And yet is seems plausible that the alignment 
of the skilled working class with the Liberal Party set the stage for subsequent developments. More generally, our data analysis suggests a simultaneous relationship between a party's support base and its programmatic appeal. Working class alignment with the Liberal Party that existed already in the Mid-Victorian era laid the basis for the subsequent progressive platforms of the Liberal Party that, in turn, cemented its support amongst working class voters. ${ }^{1}$

There are several reasons to believe that our insights hold more generally. Extending our analysis to aggregate data from a large sample of constituencies we find that voter eligibility is negatively correlated with proxies for the share of unskilled working classes in the population, whose voting patterns in the aggregate data closely resemble our findings in the restricted sample. The aggregate data thus suggests that our findings might generalise to these segments of the Victorian voting population and so provide an accurate picture of partisan alignment in Britain at that time.

Moreover, it seems likely that our insights travel beyond 19th century Britain to a broader set of parliamentary democracies. Institutional features such as the centralisation of agenda-setting power within the executive gave shape to British parliamentary democracy. They stimulated the development of parties standing on coherent programmes outlining their plans for government and were mimicked elsewhere. That these features are correlated with partisan and class alignment in the United Kingdom suggests that similar historical patterns exist elsewhere. As described by Strøm (2000), the conceptual essence of Parliamentary government is a "historical evolution" - an accident of 19th century Britain that spread to other parts of the world."

Finally, it is worth remembering that 19th century Britain was a developing country and so our insights might extend over time to those countries that are developing today. Indeed our finding that a relationship between parties and voters coincided with the

\footnotetext{
${ }^{1}$ For microfounded models of the the relationship between policies and support bases see Krasa (2018) and Howell, Krasa, and Polborn (2017).
} 
development of programmatic parties without national bases of organisation chimes with recent work in political development mentioned earlier. These lessons may be informative in understanding how developing countries today could move from a clientelistic system to one with programmatic parties (Hicken 2011; Stokes 2005; Wantchekon 2003).

\section{Institutional Setting and Data}

\subsection{Victorian Era British Political Landscape}

Elections in Britain in the Victorian period under investigation took place under the first-past-the-post voting system that is still in place. Whilst some constituencies were single-member constituencies, most constituencies elected two candidates and a few elected three and four. From around 1850 constituency elections were contested by candidates who aligned with one of two major parties, the Conservatives and the Liberals. The Liberals brought together a loose coalition of (mainly) Whigs, Radicals, and Peelites (a faction that had broken from the Conservatives) and by 1860 formed a cohesive parliamentary block. For convenience, for our analysis of the years prior to the formation of a cohesive Liberal Party identity we refer to candidates who are either Whig or Radical as Liberal.

In the period of analysis, the key institutional reforms were the Great Reform Acts. The first of these, introduced in 1832, introduced several measures that mitigated malapportionment: increasing representation in the industrialized cities, and taking away seats from the so-called rotten boroughs with small voting populations. The act also increased the male franchise to around 650,000. The Representation of the Peoples Act, otherwise known as the Second Reform Act, was passed by Parliament on August 15th, 1867. The Second Reform Act, that became law in England and Wales in 1867, extended the franchise in the boroughs to all males over the age of 21 who were 
inhabitant occupiers, whether house-owners or tenants, and to male lodgers whose rent was at least 10 pounds per year. A residence of at least one year in the borough was required. In counties, the franchise was extended to holders of life interests, copyholds and leases of sixty years and more worth 5 pounds per annum (from a previous threshold of 10) and to tenants occupying land worth 12 pounds (from a previous threshold of 50 pounds per annum).

\subsection{Poll Book Data}

Prior to the next major reform, the Ballot Act of 1872, individual voting records of registered voters were public and recorded in so called poll books. This historical fact provides a novel and reliable window into actual individual political behaviour. Using these data, we can answer questions previously addressed using less detailed aggregate or less reliable survey data. While Andrews (1998) shows that poll book data may contain some errors, they are so rare that they will be insignificant to any empirical analysis. The main limitations are, in fact, that the information content of the poll books are somewhat limited. We have obtained poll books with the occupations and information before and after 1865 for three constituencies. Our analysis of these micro-data confirms the general findings of Cox $(1984,1986,1987)$ based on aggregate data while yielding new insights into the mechanism explaining the emergence of a party-oriented electorate.

Previously, poll book data have been used mainly in historical research (Drake 1971; Speck and Gray 1970; Mitchell and Cornford 1977; Phillips 1992; Phillips and Wetherell 1995), where the empirical analysis has been very elementary in nature. Accordingly, in a more recent work Andrews (1998) states that "some work has been done on poll books but in general this has been confined to an overview of poll books, or as illustration of a point in another argument". Indeed, Andrews' own descriptive work is rare in that it utilizes the data in detail and shows that voters in Sandwich change the party they vote 
quite often over time. He supplements this with evidence from other historical records such as candidates' accounts to conclude that extensive vote buying took place.

Our focus is on the period after the First Reform Act of 1832 and before The Ballot Act of 1872. We use only poll books that contain information on occupation and cover the transition period from candidate to party-oriented system, that is, 1857-1868 as discussed by Cox (1986). Given these restrictions, we make use of poll books for a varying number of general elections held in three boroughs in South-Eastern England: Ashford (four elections in 1852-1868; Drake and Pearce 1992), Sandwich (eight elections in 1832-1868; Andrews 2001) and Guildford (eight elections in 1832-1865; Sykes 1977). ${ }^{2}$ We show the location of these constituencies in Appendix S1 (p. 4). ${ }^{3}$ Digitized versions of the poll book content are provided by the UK Data Archive (Ashford, UK Data Archive Study Number 2948; Sandwich, 4170; Guildford, 977). All poll books record voters' names and votes. Moreover, Sandwich and Guildford poll books include also occupations of the voters. For Ashford, we obtain the occupation information for a fraction of the voters by linking the data with censuses conducted around the period, directories that also contain occupational information for some of the voters and lists of landowners. We use a fuzzy merging algorithm, allowing minor differences in spelling of the first and last names, to link three censuses (1841, 1851 and 1861), directories from

${ }^{2}$ Ashford was not an independent constituency but part of the constituency of Kent Eastern.

${ }^{3}$ Furthermore, the map shows the location of other constituencies for which we have obtained similar poll books, but which do not include elections from the our period of interest. While we do not use them in this study, the map shows that occupation information was collected more widely. There are also more poll books available electronically that do not contain any occupation information. 
1851, 1855, 1867 and 1874 and lists of land owners to the poll book data. After this, we assign each voter occupational and class information from the closest available source.

An example of the typical content included in our poll books is illustrated below in Figure 1 which shows two pages from Sandwich poll book for parliamentary elections held in 1857. The information contained in these pages tells us for instance that Luke Jarvis, a publican from Deal, split his vote between two Liberal candidates: E. H. K. Hugessen, and Lord Clarence Paget.

We have further classified the occupations in working and middle classes in order to evaluate class differences in voting behaviour. Our classification follows Best (1972) and Clapham (2009), where the main classification criteria is a typical income of each occupation. Appendix S1 presents additional details on the data. First, we describe the occupational composition of different classes (p. 5). Second, we report descriptive statistics on voting behaviour by class and constituency (p. 6). ${ }^{4}$ Finally, we report election results for the elections covered in our data in Appendix S1 (p. 7). For Ashford we report the election results from the entire constituency of Kent Eastern. There are typically three or four candidates competing for two seats which means that the composition of the candidate pool remains relatively stable throughout the time period we study. Thus, it is not likely that our findings would be driven by changes in the available electoral candidates.

[Figure 1 about here.]

\footnotetext{
${ }^{4}$ In Sandwich and Guildford working class tends to give more split votes but party preferences are similar across classes. In Ashford, the working class gives less split votes and votes more for the Liberals than the middle class. However, this difference between constituencies will turn out to be mainly a result of different election years rather than within election year geographic differences.
} 


\section{Regression Analysis}

\subsection{Partisan Alignment}

Political parties with close ties to the electorate are a key feature in the historical development of parliamentary democracies. When and why did such connections arise? The question is difficult to address since, as noted by Duverger, and as noted earlier, there are a myriad of factors that can plausibly explain the emergence of a partisan electorate. One approach, that we follow and extend here was pioneered by Cox in a sequence of papers and a monograph $(1984,1986,1987)$, who looked at within country variation in split voting over time to understand the timing of key changes.

During the 19th century, most English constituencies elected two MPs under plurality rule. Cox's intuitive argument was that party-oriented voters would not split their votes between the Liberals and Conservatives. Split votes do not affect the seat allocation between the parties. They do, however, affect which candidates are elected within a party. Cox showed that split voting (his key indicator of a candidate-centred electorate) declined dramatically during $1857-1868$, and so before the first election under the new extended franchise in 1868.

Since Cox's studies it has been understood that cohesive parties with close links to the electorate preceded the major reforms to the franchise in the late Victorian period, namely the Second Reform Act of 1867 that enfranchised the unskilled working classes, the Corrupt Practices Act of 1883 that made it harder for candidates to bribe voters, and the 1884 Reform Act that extended suffrage in the rural counties. Cox $(1984,1986,1987)$ used descriptive analysis of a long and wide panel of aggregate, constituency-level data to show that the party orientation of Victorian voters occurred, i.e. the share of split votes declined, a decade or so before these defining institutional changes, thus challenging the conventional wisdom (see for example Nossiter 1975) that Victorian voters aligned with political parties because of those reforms. He highlighted instead the 
decline in parliamentary prerogative in the Mid-Victorian period that, when combined with the centralisation of decision-making authority within a cabinet and the Prime Minister's power of dissolution and use of the confidence vote, weakened the role of the individual MP. A party-oriented electorate developed as voters used their votes to control the executive and choose between rival teams: an incumbent government and (Her Majesty's Loyal) opposition. ${ }^{5}$

Cox's analysis of Victorian England remains a seminal study for understanding the role of parties in parliamentary systems more generally. The institutional developments that Cox describes as bolstering the development of cohesive parties with close links to the electorate are, of course, found in other parliamentary democracies and so have been the subject of a large body of theoretical and empirical research (Huber 1996; Diermeier and Feddersen 1998).

Despite the seminal nature of Cox's claims, they rest on the use of aggregate data from constituency elections in nineteenth century Britain. These constituencies differ in many unobserved ways, making it hard to support any causal claim regarding what kind of voters or constituencies in particular changed their voting behaviour. The use of aggregate historical data to draw inferences about party alignment within the electorate is problematic as inferences from aggregate data are subject to the well understood ecological fallacy. Moreover, very different behavioural patterns could be associated with the same vote share, making any inference difficult to sustain. For example, a party might obtain $50 \%$ of the vote share when half of all voters cast both votes for that party

\footnotetext{
${ }^{5}$ Recent work by Eggers and Spirling (2016a) using micro-level data on parliamentary votes confirm that parties became cohesive in this period and that this is due to changes in individual behaviour. Eggers and Spirling (2016b) study speech patterns in parliament to show the centralisation of agenda-setting power by the executive and the emergence of a shadow cabinet.
} 
or when each elector casts a split vote. A more specific problem - that we discuss in Section 4.3 and our supplementary materials - arises due to the fact that, when franchise restrictions are in place, we cannot accurately infer the population of eligible voters. One of our contributions is in being able, for the first time, to use individual-level voting data, recording actual individual-level voting returns, in order to address these issues.

Revisiting Cox's question on the timing of key changes in the English electorate, we can check whether regression analysis of our individual-level data corroborates those earlier findings. Our micro-level analysis allows us to go much further, however, in exploring which behavioural voting patterns underpin the decline in split level voting and the apparent emergence of a partisan electorate.

Cox's main finding was that split level voting had declined by 1865 and almost to the level that persisted from 1868 onwards, thus prior to the major institutional change in 1867. However, during the election year 1857 split voting was as common as in the previous era. In 1859 split voting was lower than in 1857, but still within the variation of the previous era. We use these findings to split our sample into two periods: the first contains elections before 1865; the second, those during and after 1865 . We use this classification to conduct difference-in-difference estimation (DID) that allows us to assess whether in the critical periods the response of the working class was different to that of the middle class. ${ }^{6}$ From this perspective, working class can be seen as the treatment group, and middle class as the control group in the DID.

While our concern is to provide descriptive results on the timing of changes in political behaviour for different classes, one could give a causal interpretation to these results if standard DID assumptions are met. The common trend assumption means that absent a general shift from candidate-oriented to a party-oriented system, the outcome of interest for the working class and middle class would have evolved with the same trends. We

\footnotetext{
${ }^{6}$ Our results do not rely on this particular before-after classification as we show in the robustness analysis section by reporting a separate estimate for each year.
} 
provide the standard indirect test of this by testing for the common pre-treatment trends. Moreover, a causal interpretation would require that any change in the behaviour of the working class in the post-treatment period did not cause a response in the behaviour of the middle class, i.e. there should be no spill-overs caused by the effect of interest. If both of these assumptions hold, a causal claim could be made. However, if not, then DID regressions and graphical illustrations typical to the DID still provide a useful way of describing the phenomenon of interest. Our benchmark specification is as follows:

$$
\begin{aligned}
y_{i t}=\alpha & +\beta_{1} 1[\text { Working class }]_{i t}+\beta_{2} 1[\text { Year } \geq 1865]_{t} \\
& +\beta_{3} 1[\text { Working class }]_{i t} \times 1[\text { Year } \geq 1865]_{t}+\varepsilon_{i t},
\end{aligned}
$$

where $y_{i t}$ is the vote choice of voter $i$ in election $t$ (dummy for casting a split vote in Table 1, and dummy for Liberal vote in 2). 1[Working class $]_{i t}$ indicates whether the voter belonged to the working classes, and $1[\text { Year } \geq 1865]_{t}$ is an indicator for the election happening in or after the year 1865 . We estimate (1) either separately for each constituency or using a pooled data from all of them, restricting the sample to those voters who turn out to vote. We use either no controls or election year fixed effects. Note that when we include the election year fixed effects, we omit $1[\text { Year } \geq 1865]_{t}$ as this is already captured by the year dummies for 1865 and 1868. For Guildford, we also observe more detailed location (parish) information within the constituency and therefore include that locality fixed effect. With the pooled data, we control for the election-constituency fixed effects.

The regression results for split voting are presented in Table 1. From the separate regressions we find that working class status is a strong and robust predictor of split voting prior to the 1865 elections (the coefficient related to the variable 1 [Working class]). In Guildford and Sandwich this result is significant, but it is imprecise in Ashford. However, in elections during and subsequent to 1865 we observe that split voting goes 
down for all voters (the coefficient related to the variable $1[$ Year $\geq 1865]$ ). This result is highly significant in all constituencies and exactly in line with the aggregate level results of Cox.

Our data allows us to go further in assessing heterogeneous effects. In particular, we provide new findings on the evolution of class-based voting. We observe that subsequent to 1865 , the split voting goes down even more for the working class than the middle class (the coefficient related to the $1[$ Working class $] \times 1[$ Year $\geq 1865]$ variable). This main effect of interest is present and robust within all constituencies, but statistically significant only for Sandwich. The pooled analysis confirms these findings and all the results are significant in the pooled analysis.

As to the interpretation of the coefficients, let us look at specification (6) as an example. In Sandwich and prior to $1865,10.6 \%$ (Constant $=0.106)$ of the non-working class voters gave split votes and $14.5 \%$ of the working class did so (Constant +0.041 ). After and during 1865, 5.8\% of the non-working class voters gave split votes (Constant - 0.048) and $6.1 \%$ of the working class did the same (sum of all the reported coefficients). Therefore, while we observe that split voting decreased across classes the decrease was relatively large amongst the working class. More specifically, the reduction in split voting amongst the working class was large enough to bring them to the same level observed in the middle class.

In order to visualise our data and the estimation exercise, we plot the share of split votes among the two classes over time (Figure 2). Our discussion of these results is based on the bottom-right graph that uses the pooled data. However, for completeness, we also report separately the individual constituency graphs that deliver the same main message (albeit with more noise due to obvious sample size reasons).

Doing so we first observe that the split vote share has reasonably common pre-treatment trends for working and other classes prior to the 1865 elections. This indirectly implies that the common trend assumption may be realistic and so might 
allow some causal claims to be made concerning the main association of interest reported in Table 1. The second key observation is that prior to 1865 split voting is always more common among the working class than the middle class. The third key observation is that for the 1865 election, split voting is about as common in both the groups and in 1868 slightly less common among the working than the middle class. Finally, and critically we note that the decrease in the split vote share among the working class was in place already in 1865 and not only in 1868. This is important because the 1868 elections were affected by the franchise extension of 1867 (Berlinski, Dewan, and Van Coppenolle 2014). Thus we observe that the decline in split ticket voting amongst the working class precedes the main institutional change of the Victorian era.

In Appendix S1, we illustrate the same findings further by plotting over time the class means of the residuals from a regression where split voting is predicted with only the election year fixed effects (p. 7). The graphs focus on the relative differences between the classes, while cleaning out the variation due to time in the occurrence of split voting. The graphs show quite clearly the extent to which the behaviour of working class voters converges with that of middle class ones with respect to split voting. Our results thus corroborate Cox's findings and go further in showing that the development of a partycentred electorate in Victorian England owes much to the change in behaviour of the English working classes.

[Table 1 and Figure 2 about here.]

\subsection{Party Alignment}

We have shown that a partisan electorate emerged in the United Kingdom in the period prior to the major institutional reforms and that the main driving force was a change in the voting behaviour of working class voters. What effect did this have on the emerging party

system? The existence of the classic two-party class-based system based on alignment of the British working class with the left Labour Party (and the corresponding alignment of 
the middle classes with the Conservatives) is shown through survey evidence from the postwar period (Butler and Stokes 1969) -much of the subsequent literature documented its decline. In the absence of survey data from earlier periods it is hard to show the origins of class alignment, although there is some evidence that the two-party class-based model was already in evidence in the interwar period and by the time Labour replaced the Liberals as the main party of the left. ${ }^{7}$ A plausible, though not yet substantiated claim, is that a two-party class-based system (albeit one of a different form) emerged much earlier in Britain. ${ }^{8}$

In Table 2, we analyse how party voting behaviour changes over time. ${ }^{9}$ We ask whether the working class voted Liberal more often than other classes prior to the 1865 election and whether they did so in 1865 and 1868 elections. The analysis is identical to

${ }^{7}$ Estimates showing this effect, and using corrected constituency level aggregate data, were presented in earlier work by Carles Boix at the 2001 meetings of the Midwest Political Science Association.

${ }^{8}$ As noted by Cox $(1987$, p. 162):

"At some point between the elector in 1851 who observed that, 'as a tenant-farmer, I well know that when we are given to understand which way our landlord means to vote, and are canvassed by his steward and lawyer, we quite understand which way we are expected to go,' and the elector in 1951 who asserted, rather more succinctly, 'I would vote for a pig if my party put one up,' voting behaviour had clearly changed considerably."

${ }^{9}$ Our conclusions are robust to assigning the outcome variable value 0.5 if a voter casts a split vote between the parties, although this tones down the magnitude of the estimates slightly. 
the previous DID analysis on split voting bar the difference in outcome variable. Again, the main coefficient of interest relates to the interaction variable between working class status and the latter time period. This can be seen as a difference-in-differences estimate of left voting amongst the working class in the post 1865 era.

Consistent with the results on split ticketing, we find that during the earlier period, working class status is a predictor of casting split votes or voting Conservative rather than Liberal in Guildford and in Sandwich. For Ashford there is also a positive correlation but this finding is not statistically significant. In Ashford, in the 1865 and 1868 elections, the Liberal party became much more popular among the middle class than in the earlier period and this change is statistically significant. In Sandwich and Guilford there is not much change in the popularity of the Liberals among the middle class. However, in the latter period, and in all three constituencies, the popularity of the Liberals amongst the working class increased. This effect of main interest is robust when including controls within all the constituencies, and the effect is of similar magnitude across constituencies.

In order to interpret these coefficients, we again look at specification (6) in Table 2. Prior to $186552.3 \%$ (Constant $=0.523$ ) of the middle class voters voted Liberal in Sandwich and $45.1 \%$ of the working class did so (Constant - 0.072). After and during $1865,54.1 \%$ of the non-working class voters voted Liberal (Constant +0.018$)$ whereas $56.1 \%$ of the working class did so (sum of all the reported coefficients). Thus, whereas the middle class Liberal support stayed the same, there was a substantial change in the behaviour of the working class. In sum, we observe an emerging alignment between the working class and the Liberal Party that, as in the decline in split ticket voting, predates the major institutional reforms of the late Victorian era.

We visualise the evolution of Liberal voting by class in Figure 3. Again, a similar visualisation using regression residuals can be found in Appendix S1 (p. 8). When comparing pre-treatment trends between classes with those concerning split voting (Figure 2) it is less clear that (with respect to class voting) there are indeed common 
trends. This makes a causal interpretation of our findings with respect to the timing of the class basis of partisan voting harder to defend. The second key observation is that typically the Liberals were more popular among the middle class than the working class in the earlier period, whereas in all constituencies the opposite was true in the latter period. The increase in the Liberal vote share among the working class took place already in 1865 and not only in 1868, that is, already before the 1867 reform.

In our supplementary materials (Appendix S1, p. 8), we repeat the estimations using a sample of by-elections in Guildford (1858 and 1866) and Sandwich (1841, 1852, 1859 and 1866). In such elections, the constituents were electing only one candidate to replace a politician whose term was terminated prematurely (for example, due to the politician passing away). Therefore, the voters did not have the possibility to cast split votes and the analysis allows us to verify that the observed change in Liberal voting is also present nevertheless. The voting behaviour of the working class voters changed very similarly after 1865 even in by-elections.

Analysis of our data thus reveals that the probability of Liberal voting was already significantly higher amongst working class voters in 1865, prior to the introduction of the Second Reform Act and the introduction of the Secret Ballot in 1872 that was introduced in part as a way of reducing the political power of patrons over tenants. ${ }^{10}$ With respect to British politics this finding is significant in providing the first solid evidence that support for the Liberal Party amongst the enfranchised skilled working class predates the emergence of the more progressive or $\mathrm{New}$ Liberalism and was established already during the Mid-Victorian era. That the genesis of the British two-party class- based system was already in place at this time suggests that subsequent developments are related to this fact. For example, it seems plausible that the emergence of a Liberal Party under Gladstone with a radical programme of reform that appealed to

${ }^{10}$ Studies of the introduction of the Secret Ballot elsewhere shows strong evidence of its impact on the voting behaviour of relatively poor voters (Baland and Robinson 2008). 
the newly enfranchised working class built on an existing alliance between workers and Liberals and, in turn, reinforced this relationship.

In sum, we find evidence that two empirical trends - the party orientation of voters and the class basis of party voting - predate the defining institutional changes of the Victorian era. But while we do find evidence of a strengthening link between class and voting behavior, the regression coefficients are small compared to levels. It appears that class-based voting was still in its infancy in the 19th century. A common metric of classbased voting is the so-called Alford index (Alford 1963). The measure is computed by subtracting the percentage of middle class voters who vote for the liberal candidates from the percentage of working class electors who vote for the liberal candidates. Our data yields an Alford index roughly equal to -3.4 for the period before the year 1864, and 4.4 after that. We can contrast our numbers, for example, with those of Alford who studied British opinion polls over the period 1952-1965. He found that the index averaged around 40. Thus, factors other than class were potentially more important for voting behavior in Victorian England. ${ }^{11}$

[Table 2 and Figure 3 about here.]

\subsection{Sensitivity Analysis}

Causal claims based on our DID estimates rest on the assumption of common trends. In Figure 4, we indirectly test this assumption by verifying that both outcomes have common pre-treatment trends. We achieve this by estimating the following model

${ }^{11}$ Our evidence also suggests that farm workers (who were part of the working classes) did not yet become significantly more likely to vote for the Liberals around and after 1865 . This may partially explain why the Alford index in our data is lower than that found in later opinion poll data. For detailed results, see Table SI6 in Appendix SI2. 
resembling a typical dynamic difference-in-differences (or event study) specification:

$y_{i t}=\gamma+\delta_{1} 1\left[\right.$ Working class $_{i t}+\sum_{t \neq 1859}\left\{\delta_{2 t} 1[\right.$ Year $=t]+\delta_{3 t} 1[$ Year $=t] \times 1\left[\right.$ Working class $\left._{i t}\right\}+\zeta_{i t}$.

Figure 4 reports only the $\delta_{3 t}$ coefficients for each $t$ using pooled data from all constituencies. We set the base year to 1859, i.e. the last year before our treatment period. The last two coefficients (1865 and 1868) relate to the actual treatment period of interest. That actual result of interest is robust to allowing a different coefficient for each year, since three out of four coefficients are statistically significant. If, however, the coefficients related to years prior to 1865 were shown to be statistically significant then the hypothesis of common pre-treatment trends would be rejected. In one out of 14 cases this is in fact the case. While this may be an indication of potential issues, it may also be due to multiple testing.

Further sensitivity analyses is in Appendix S2. There we use alternative social class divisions, reclassifying voters mimicking Eriksson and Goldthorpe's (1992) five-class scheme as closely as possible. This analysis reveals that the decline in split votes comes mainly from non-skilled and skilled workers (p. 10). Second, we verify that the alignment with the Liberals happens among non-skilled and skilled workers (p. 11). Third, we show robustness to excluding voters voting for the first time after the Second Reform Act of 1867 (p. 12). A concern is that the results could be driven by new voters being more liberal. Our results suggest that this is not the case. ${ }^{12}$ Finally, (as we observe

${ }^{12}$ See also Berlinski and Dewan (2011) who study the political consequences of franchise extension. They show that there is no evidence relating Liberal support to changes in the franchise rules, although the Second Reform Act did affect electoral competition and candidate selection. 
some voters multiple times in the data) we include voter fixed effects (p. 13). This does not change our key conclusions.

[Figure 4 about here.]

\section{Ideological Appeal or Decline in Vote Buying?}

What explains the development of emergence of a party-oriented electorate at this time? Or, as Duverger asked "how did we pass from the system of 1850 to that of 1950 "? Having shown that a key factor (already in Mid-Victorian England) was an alignment of the working classes with the Liberal Party, we next try to understand the mechanisms that lie behind that alignment. According to Duverger the key factors that lead to the emergence of party-oriented systems were the extension of popular suffrage, the role of parliamentary prerogatives, and the emergence of organized mass parties on the left who connected with working class voters on the basis of ideology.

We have shown that two empirical trends - the party orientation of voters and the class basis of party voting - predate the major franchise reform of 1867. By extension it can not be the case that organized mass parties played a role, for they did not exist at that time. As shown by Hanham (1959), the process of developing national party organisations able to support country-wide candidacies and campaigning activities did not begin until after the Reform Act of 1867. Prior to this, political parties in the United Kingdom were quintessential cadre parties, as defined by Duverger, namely coalitions of legislators who voted together on issues and stood for election on a common programme. The need for parties to develop coherent programmes was enhanced by the decline in parliamentary prerogative and centralisation of executive power that occurred a decade or so prior to the major institutional reforms. It is plausible then that, on the basis of such programmes, and even in the absence of mass party organisation, an ideological affinity emerged between the skilled working classes and the Liberal Party. 
However, there is another plausible explanation that relates to the fact that 19th century elections were characterized by the presence of vote buying. Political parties and candidates offered voters money or other types of benefits in exchange for their votes and even gathered information on voters' debts, crimes and infidelities to gain leverage over them (Stokes et al. 2013; Camp, Dixit, and Stokes 2014). As shown in several studies, the introduction of the secret ballot in 1872 led to a substantial decrease in vote buying (Cox 1987; Kam 2017). Camp, Dixit, and Stokes (2014) argue that the changes in political and economic environment before the ballot reform were also important. As larger groups were enfranchised and the median income of the electorate increased, bribing voters became more expensive and less beneficial for the candidates. Closely related to these arguments, Cox (1987) links the decline of vote buying in 19th century England with the growth of electoral constituencies which also meant that a fixed amount of money would buy a smaller proportion of votes. Moreover, Cox argues that the power of individual MPs was declining during the 19th century. For instance, while individual MPs were previously processing private bills which conferred, for example, divorces, canals and railroads, these among some other responsibilities were moved to courts and bureaus. As local lords could benefit less from having their own MP, also the incentives to buy votes became smaller.

The argument that vote buying was a problem in Mid-Victorian England but became less so towards the 1872 reform raises an important question: Was the decline in split voting and working class alignment with the Liberals merely due to vote buying becoming less common? We can shed some light on this question by focussing on the behaviour of occupational groups that were likely to be particularly susceptible to vote buying. In particular, we identify occupational groups that were prone to changing their voting behaviour across elections before 1865 , and define volatile and consistent groups 
of voters. ${ }^{13}$ In Appendix S3 we show that being a consistent working class voter is only weakly associated with split voting after 1865 (p. 15). On the contrary, most of the decrease in split voting comes from voters belonging to the volatile occupation groups who change their voting behaviour. The estimates are much larger in absolute terms and statistically highly significant. This is perhaps what one would expect to see, if we have indeed classified those groups affected by vote buying properly and vote buying became less common during our post-treatment period.

${ }^{13}$ First, we define a dummy for each voter and election on whether they changed their voting behavior from the previous election. For example, consistent split voting is defined as consistent voting behavior and moving from split voting to Liberals is volatile behavior. Second, we calculate the mean over these dummies for each occupation. Third, the occupation is defined as volatile if it is above 50th (or 75th in the other specification) percentile in this mean variable. Previous literature on Victorian voting behaviour has argued that some occupational groups were more prone to vote buying than others and this is reflected in them switching their voting behavior more (Andrews 1998). For instance, local lords could pressure small entrepreneurs such as shopkeepers by threatening with boycotts if they did not cast at least one vote for the lord's candidate (Cox 1987). Hence, it is justifiable to define the vulnerability to vote buying at the occupational instead of the individual level. Another rationale for this choice is that an individual voter changing his voting decisions once or twice may be entirely normal but a large fraction of voters in a whole occupational group changing its voting behaviour would lead one to suspect vote buying. Moreover, more than one election would probably be needed to define the likeliness of being affected by vote buying at the individual level. This would mean unnecessary loss of some data. 
Furthermore, we observe that both the consistent working class and volatile working class voters aligned with the Liberals (p. 16). The estimates are positive and statistically significant and slightly larger for the volatile voters. We can conclude then that working class alignment with the Liberals cannot be completely explained by a decline in vote buying. This suggests that other factors were important also. While we do not directly observe the effect, the patterns in our data are consistent with claims that working class voters were attracted to the programmatic appeal of the Liberal Party. Stokes et al. have argued that the diminishing role of agents reduced the advantages of vote buying and so led parties to develop different (ideological) appeals that targeted groups of voters rather than individual ones. Such programmatic appeals can be seen as a coordinated partisan response to the institutional and socio-demographic changes that broke the stranglehold of the brokers and aligned groups (or classes) of voters with parties on the basis of ideology.

Recently, others have argued (alongside Stokes) that such programmatic appeals are a critical element in political and economic development (see Acemoglu and Robinson 2012, Chapter 11). For example, Fujiwara and Wantchekon (2013) argue that programmatic appeals can enhance welfare and use evidence from Benin that such appeals are also optimal for candidates under some circumstances. We view our analysis as complimentary to that of Stokes. Whereas she provides case study evidence that parties were incentivised to develop ideological appeals, ours is (we believe) the first quantitative analysis that is consistent with the claim that voters responded to such appeals.

\section{External Validity}

The advantages of using rich data such as ours means that we can avoid some pitfalls when making inferences from more aggregated data. A limitation of our poll book data is 
that they are available for only three constituencies that may well differ from each other and from unobserved constituencies. To assess the generalizability of our findings, we contrast some patterns in our data to those in aggregate data. ${ }^{14}$ We combine electoral data from Eggers and Spirling (2014) with the 1861 census obtained from the UK Data Archive (Gatley et al. 2000). ${ }^{15}$

The first notion that arises from comparing the poll book data with census data is that our constituencies have fewer working class residents than is typical. In Figure 5, we report a histogram of working class shares while marking the location of our three constituencies, based on poll book data (Sandwich) or the census (Ashford and Guildford), by vertical red lines. We use the 1861 census information to measure the working class share in these constituencies, and include only constituencies which have

${ }^{14}$ In Appendix S4 (p. 20), we also show that the composition of the electorate in our poll book data is not drastically different to the composition in six other constituencies for which we were able to obtain poll books with occupation information, but for a more limited time period). Our on-going work documents that these constituencies are fairly representative in terms of geography and demographics (results available upon request). ${ }^{15}$ The Eggers and Spirling (2014) data are available online at http://andy.egge.rs/data.html (accessed August 24,2019). Besides limiting the data to constituencies that we could link with the census info, we restrict the sample to constituencies that are present for more than five elections between 1835 and 1868 (we omit the entire year 1832, because the data are relatively scarce then). Moreover, we only include constituencies that are present in both our before and after periods. These restrictions are needed to ensure comparison of how voting behaviour evolves in the same constituencies over time. This leaves us with 117 constituencies. 
elections in 1859. The census is available for Guildford, but not for Sandwich. For Ashford, we use the census information from Kent, which Ashford is a part of.

Nevertheless, we also document tentative descriptive evidence that patterns from our micro-data exist may be present more broadly. We report how the Liberal vote share evolves in municipalities in two groups with above or below median share of working class in Figure $6 . \quad$ This analysis attempts to graphically mimic our difference-in-difference analysis at the aggregate level. Liberal voting does not increase around 1865 in constituencies with less working class population, unlike it does in working class dominant constituencies. In Appendix SI4 we show that the pattern is likely driven by low skilled working class population (p. 19). This evidence should be treated merely as tentative evidence given that none of the estimated effects turn out to be statistically significant (not reported).

There are also other limitations: (i) the analysis takes places between rather than within constituencies; (ii) we only observe working class share for one census year; and (iii) the occupation information in the census follows a more aggregate classification than the poll book information, and (iv) we do not have information on the share of eligible voters, neither overall nor (and in particular) within each occupation. The last point implies that we cannot separate whether a (possible) correlation between working class share and the Liberal vote share is driven by voter alignment or by the eligibility to vote. For example, comparing across constituencies using aggregate data one might find that working class share is negatively correlated with Liberal vote share, even though, at the individual level, working class voters are more likely to vote Liberal. This is due to the possibility that, because of franchise restrictions, as the share of working class in a constituency goes up then the share of middle class voters goes up. We discuss this issue further in Appendix SI4 (p. 17-21).

[Figures 5 and 6 about here.] 


\section{Conclusions}

Why do political parties develop in they way they do? We have presented new evidence based on micro-level data from the Victorian period. In these, our concluding remarks, we relate our findings to previous findings on party development. In particular we connect to two main strands of literature: one takes an institutional approach in viewing parties as solutions to collective dilemmas; the other has a sociological focus, seeing parties as representative of specific societal groups.

A classic work within the first strand is that of Aldrich (1995) who wrote on the development of American parties. He highlights the role that parties played in resolving the problems of vote cycling in legislatures, those involved in the collective action of mobilizing voters, while providing career paths for ambitious politicians. For example, in chapter 5, he shows how Jacksonian Democracy was cemented by an alliance between Van Buren and Jackson: The former organized the democratic caucus while the party organisation provided electoral resources for state level politicians who adopted the Jacksonian label. At the same time, the flip-side of the national Democratic bargain involved the national party yielding local autonomy to state politicians on the key policy issues. By contrast the British political system described by Cox (1987) was more centralised. Cox argues that a party-oriented electorate emerged due to changes in the structure and power of the executive and as a result of increasing demands on Parliaments time. According to Cox $(1984,1986)$ these changes and their consequences on party development preceded the major franchise reforms of the late nineteenth century.

A different perspective sees party development as reflecting broader societal factors. For example, La Palombara and Weiner (1966, p. 41-42) focus on "parties as a consequence of the development process" and as the "culmination, as it were, of social, economic and political change." According to Von Beyme (1985), the connection between social change and parties comes via ideology. He showed that parties in 
democratic regimes in the nineteenth and twentieth century can (almost always) be classified as belonging to identifiable families spirituelle that share a common ideological perspective. Building his classification on exhaustive documentation of party votes shares, programmes and organisational details, he shows that parties originated as representative of particular interests that prevailed at the time of their inception. Their role was developing a clear set of ideas and principles, embodied in the party programme, that reflected the concerns of such interests. Because different countries follow similar development paths, party development thus follows a familiar pattern. In the case of the Liberals (chapter 5) they developed a programme that represented the interests of commerce and manufacturing, whereas their rival Conservatives were connected to landed interests.

Our contributions to this literature are several. Our micro analysis of voting data corroborates Cox's claims that a party-oriented electorate emerged in the United Kingdom prior to the major suffrage reforms (of 1867, 1872 and 1884) and so supports the view that British parties emerged as a resolution to the collective dilemma faced by legislators in Parliament. Going further, we connect to the second main strand of literature, providing new evidence that the emergence of a party-oriented electorate was in large part due to the increasing party orientation of working class voters. These voters were increasingly likely to vote for the Liberal Party. Furthermore we show that the mechanism behind this class alignment was programmatic appeal. In sum, the timing of, and mechanism explaining, the emergence of a party-oriented electorate supports the view of parties as solutions to collective dilemmas. Yet the evidence also shows that the parties that emerged were connected to occupational groupings on the basis of their programmes. Indeed, as we have argued, it is plausible that the early orientation of working class voters to the Liberals stimulated the later development of class alignment and that similar historical patterns exist elsewhere. 
Moving beyond these classic works on party development, much of what we know about the alignment of voters with parties comes from a strand of literature that generates insights from mass surveys of the electorate in the postwar period or from aggregate electoral data. Because techniques to evaluate them were established after party-oriented systems emerged, surveys will do little to help us understand the genesis of such systems and possible path dependency. Inferences drawn from aggregate data are also subject to several caveats and this is particularly so when assessing voting data when franchise restrictions are in place. Indeed, as we have shown, when assessing the propensity of specific groups to vote for particular parties, we are unable to separate whether correlations are driven by voter alignment or by the eligibility to vote within that group. Our paper has instead shed new light on the emergence of party-oriented systems using individual elector level panel data from the 19th century UK poll books.

More general lessons stem from our analysis and these are relevant both to understanding party development in the developed and developing world. With respect to the former, our analysis suggests that the genesis of Britain's class-based two-party system can be found almost a century before the survey based evidence of its existence (and subsequent decline). Intriguingly, the emergence of the observed pattern of partisan and class alignment occurred in the absence of parties with any semblance of organisation within the electorate and seems to have been formed on the basis of programmatic appeal. This speaks to recent findings by Wantchekon (2003) and Fujiwara and Wantchekon (2013) who present evidence that programmatic politics can be a viable alternative to clientelistic forms of engagement in the developing world where party organisation is thin on the ground. 


\section{References}

Acemoglu, Daron, and James A. Robinson. 2012. Why Nations Fail: The Origins of Power, Prosperity, and Poverty. New York, Crown.

Aldrich, John H. 1995. Why Parties: The Origins and Transformation of Political Parties in America. Chicago, University of Chicago Press.

Alford, Robert. 1963. Party and Society: The Anglo-American Societies. Chicago, Rand McNally.

Andrews, F. W. G. 2001. “Parliamentary Poll Books of Sandwich, Kent, 1831-1868.” [Data collection]. UK Data Service. SN: 4170, http://dx.doi.org/10.5255/UKDA-SN-4170-1 (accessed August 24, 2019).

Andrews F. W. G. 1998. “The Pollbooks of Sandwich, Kent, 1831-68.” Historical Research $71,75-107$.

Baland, Jean-Marie, and James A. Robinson. 2008. "Land and Power: Theory and Evidence from Chile." American Economic Review 98, 1737-1765.

Berlinski, Samuel, and Torun Dewan. 2011. "The Political Consequences of Franchise Extension: Evidence from the Second Reform Act." Quarterly Journal of Political Science 6, 329-376.

Berlinski, Samuel, Torun Dewan, and Brenda Van Coppenolle. 2014. "Franchise Extension and the British Aristocracy." Legislative Studies Quarterly 39, 531-558.

Best, Geoffrey. 1972. Mid-Victorian Britain, 1851-1875. Schocken Books.

Butler, David, and Donald Stokes. 1969. Political Change in Britain: Forces Shaping Electoral Choice. New York, St. Martin's Press. 
Camp, Edwin, Avinash Dixit, and Susan Stokes. 2014. "Catalyst or Cause? Legislation and the Demise of Machine Politics in Britain and the United States." Legislative Studies Quarterly 39(4), 559-592.

Clapham, John. 2009. Economic History of Modern Britain. Free Trade and Steel 1850-1886. Cambridge, Cambridge University Press.

Cox, Gary. 1984. “The Development of Party-Voting in England: 1832-1918." Historical Social Research 9, 2-37.

Cox, Gary. 1986. “The Development of a party-oriented Electorate in England, 1832-1918." British Journal of Political Science 16, 187-216.

Cox, Gary. 1987. The Efficient Secret. Cambridge, Cambridge University Press.

Craig, Frederick W.S. 1977. British parliamentary election results 1832-1885. London, Macmillan.

Diermeier Daniel, and Timothy J. Feddersen. 1998. "Cohesion in Legislatures and the Vote of Confidence Procedure." American Political Science Review 92(3), 611-621.

Drake, Michael and Carol Pearce. 1992. "Ashford, 1840-1870: a Socio-demographic Study." [Data collection]. UK Data Service. SN: 2948, http://dx.doi.org/10.5255/ UKDA-SN-2948-1 (accessed August 24, 2019).

Drake, Michael. 1971. "The Mid-Victorian Voter." Journal of Interdisciplinary History 3, 473-490.

Duverger, Maurice. 1954. Political Parties. New York, Wiley.

Eggers, Andrew C., and Arthur Spirling. 2014. "Electoral Security as a Determinant of Legislator Activity, 1832-1918: New Data and Methods for Analyzing British Political Development." Legislative Studies Quarterly 39(4), 593-620. 
Eggers, Andrew C., and Arthur Spirling. 2016a. "Party Cohesion in Westminster Systems: Inducements, Replacement and Discipline in the House of Commons, 1836-1910. " British Journal of Political Science 46(3), 567-589.

Eggers, Andrew C., and Arthur Spirling. 2016b. "The Shadow Cabinet in Westminster Systems: Modeling Opposition Agenda Setting in the House of Commons, 1832-1915." British Journal of Political Science, 46(3), 567-589.

Eriksson, Robert, and John. H. Goldthorpe. 1992. The Constant Flux: A Study of Class Mobility in Industrial Societies. Oxford, Clarendon.

Folke, Olle, Shigeo Hirano, and James M. Snyder. 2011. "Patronage and Elections in U.S. States." American Political Science Review 105(3), 567-585.

Fujiwara, Thomas, and Leonard Wantchekon. 2013. “Can Informed Public Deliberation Overcome Clientelism? Experimental Evidence from Benin." American Economic Journal: Applied Economics 5(4), 241-255.

Gatley, D. A., H. R. Southall, D. R. Gilbert, and I. Gregory. 2000. “Great Britain Historical Database: Census Statistics: Collections, 1861." [Data collection]. UK Data Service. SN: 3960, http://dx.doi.org/10.5255/UKDA-SN-3960-1 (accessed August 24, 2019).

Hanham, H. J. 1959. Elections and Party Management: Politics in the Time of Disraeli and Gladstone. London, Longmans.

Hidalgo, F. Daniel. 2012. Renovating Democracy: The Political Consequences of Election Reforms in Post-War Brazil. PhD Dissertation, University of California, Berkeley, http: // digitalassets.lib.berkeley.edu/etd/ucb/text/Hidalgo_berkeley_0028E_12656.pdf (accessed August 24, 2019).

Hicken, Allen. 2011 “Clientelism." Annual Review of Political Science 90(2), 14, 289-310. 
Howell, William, Stefan Krasa, and Mattias Polborn. 2017. "Political Conflict over Time." Working paper, http://www. econ.uiuc.edu/ skrasa/dynamicpolarization.pdf (accessed August 24, 2019).

Huber, John D. 1996. "The Vote of Confidence in Parliamentary Democracies." American Political Science Review 90(2), 269-282.

Kam, Christopher. 2017. "The Secret Ballot and the Market for Votes at 19th-Century British Elections." Comparative Political Studies 50(5), 594-635.

Krasa, Stefan. 2018. "Political Competition and the Dynamics of Parties and Candidates." Working paper, http://www.econ.uiuc.edu/ ${ }^{\sim}$ skrasa/party.pdf (accessed August 24, 2019).

La Palombara, Joseph and Myron Weiner. 1966. Political Parties and Political Development. Princeton, Princeton University Press.

Mitchell J. C. and J. P. Cornford. 1977. “The Political Demography of Cambridge 18321868." Albion 9, 242-272.

Nossiter, Thomas J. 1975. Influence, Opinion and Political Idioms in Reformed England: Case Studies from the North East 1832-74. Brighton, Harvester Press.

Phillips, John A. 1992. The Great Reform Bill in the Boroughs. English Electoral Behaviour 1818-1841. Oxford, Claredon Press.

Phillips, John A., and Charles Wetherell. 1995. "The Great Reform Act of 1832 and the Political Modernization of England." American Historical Review 100(2), 411-436.

Speck, W. A. and W. A. Gray. 1970. “Computer Analysis of Poll Books: An Initial Report.” Historical Research 43, 105-112.

Stokes, Susan C. 2005. “Perverse Accountability: A Formal Model of Machine Politics with Evidence from Argentina." American Political Science Review 99(3), 315-325. 
Stokes, Susan C., Thad Dunning, Marcelo Nazareno, and Valeria Brusco. 2013. Brokers, Voters, and Clientelism: The Puzzle of Distributive Politics. Cambridge, Cambridge University Press.

Strøm, Kaare. 2000. "Delegation and accountability in parliamentary democracies." European Journal of Political Research 37(3), 261-289.

Sykes, R. 1977. "Voting Behaviour in Guildford, 1790-1868." [Data collection.] UK Data Service. SN: 977. Available online at http://dx.doi .org/10.5255/UKDA-SN-977-1 (accessed August 24, 2019).

Wantchekon, Leonard. 2003. "Clientilism and Voting Behavior. Evidence from a Field Experiment in Benin." World Politics 55, 399-422.

Von Beyme, Klaus. 1985. Political Parties in Western Democracies. New York, St. Martin's Press. 


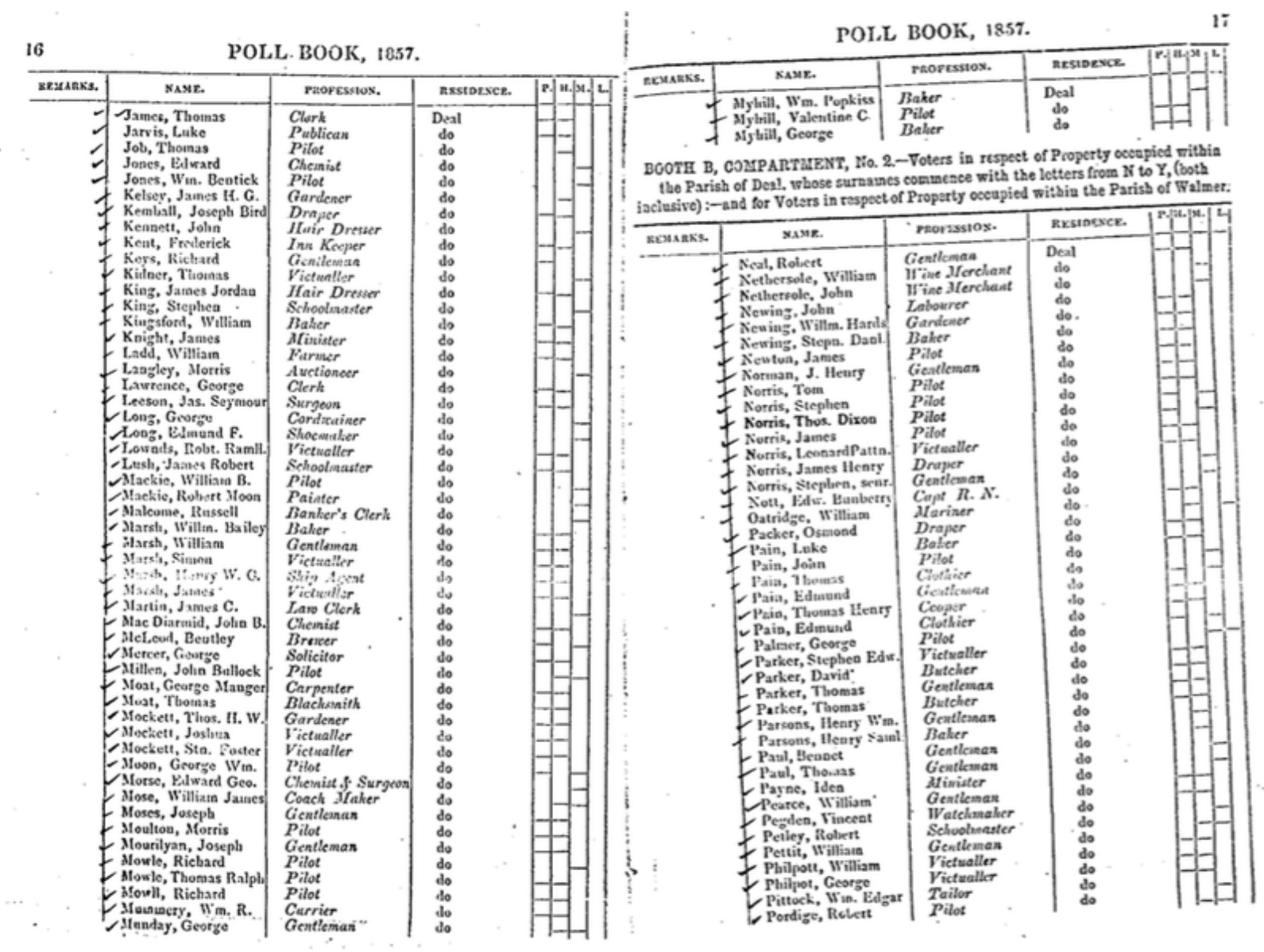

Source: See data documentation for Andrews (2001).

Figure 1. Pages from Sandwich poll book, 1857. 
Table 1. Regression results on splitting the vote.

\begin{tabular}{|c|c|c|c|c|}
\hline \multicolumn{5}{|c|}{ Panel A: Ashford } \\
\hline & (1) & (2) & & \\
\hline 1 [Working class] & $\begin{array}{c}0.024 \\
{[0.085]}\end{array}$ & $\begin{array}{c}0.024 \\
{[0.086]}\end{array}$ & & \\
\hline $1[$ Year $\geq 1865]$ & $\begin{array}{c}-0.539^{* *} \\
{[0.063]}\end{array}$ & & & \\
\hline 1 [Working class] $\times 1[$ Year $\geq 1865]$ & $\begin{array}{l}-0.036 \\
{[0.087]}\end{array}$ & $\begin{array}{l}-0.035 \\
{[0.087]}\end{array}$ & & \\
\hline Constant & $\begin{array}{l}0.582^{* *} \\
{[0.061]}\end{array}$ & & & \\
\hline$N$ & 502 & 502 & & \\
\hline$R^{2}$ & 0.40 & 0.40 & & \\
\hline \multicolumn{5}{|c|}{ Panel B: Guildford } \\
\hline & (3) & (4) & (5) & \\
\hline 1[Working class] & $\begin{array}{l}0.084^{* *} \\
{[0.020]}\end{array}$ & $\begin{array}{l}0.085^{* *} \\
{[0.019]}\end{array}$ & $\begin{array}{l}0.084^{* *} \\
{[0.019]}\end{array}$ & \\
\hline $1[$ Year $\geq 1865]$ & $\begin{array}{l}-0.170^{* *} \\
{[0.025]}\end{array}$ & & & \\
\hline 1 [Working class $] \times 1[$ Year $\geq 1865]$ & $\begin{array}{l}-0.048 \\
{[0.033]}\end{array}$ & $\begin{array}{c}-0.049 \\
{[0.033]}\end{array}$ & $\begin{array}{l}-0.043 \\
{[0.033]}\end{array}$ & \\
\hline Constant & $\begin{array}{l}0.286^{* *} \\
{[0.015]}\end{array}$ & & & \\
\hline$N$ & 3402 & 3402 & 3402 & \\
\hline$R^{2}$ & 0.03 & 0.14 & 0.14 & \\
\hline \multicolumn{5}{|c|}{ Panel C: Sandwich } \\
\hline & (6) & (7) & & \\
\hline 1[Working class] & $\begin{array}{l}0.041^{* *} \\
{[0.010]}\end{array}$ & $\begin{array}{l}0.036^{* *} \\
{[0.010]}\end{array}$ & & \\
\hline $1[$ Year $\geq 1865]$ & $\begin{array}{c}-0.048^{* *} \\
{[0.011]}\end{array}$ & & & \\
\hline 1 [Working class $] \times 1[$ Year $\geq 1865]$ & $\begin{array}{l}-0.038^{*} \\
{[0.016]}\end{array}$ & $\begin{array}{l}-0.034^{*} \\
{[0.016]}\end{array}$ & & \\
\hline Constant & $\begin{array}{l}0.106^{* *} \\
{[0.008]}\end{array}$ & & & \\
\hline$N$ & 6541 & 6541 & & \\
\hline$R^{2}$ & 0.01 & 0.04 & & \\
\hline \multicolumn{5}{|c|}{ Panel D: All constituencies } \\
\hline & (8) & (9) & (10) & (11) \\
\hline 1[Working class] & $\begin{array}{l}0.056^{* *} \\
{[0.011]}\end{array}$ & $\begin{array}{l}0.054^{* *} \\
{[0.010]}\end{array}$ & $\begin{array}{l}0.052^{* *} \\
{[0.010]}\end{array}$ & $\begin{array}{l}0.053^{* *} \\
{[0.010]}\end{array}$ \\
\hline $1[$ Year $\geq 1865]$ & $\begin{array}{c}-0.112^{* *} \\
{[0.011]}\end{array}$ & & & \\
\hline 1 [Working class $] \times 1[$ Year $\geq 1865]$ & $\begin{array}{c}-0.044^{* *} \\
{[0.015]}\end{array}$ & $\begin{array}{c}-0.044^{* *} \\
{[0.014]}\end{array}$ & $\begin{array}{c}-0.051^{* *} \\
{[0.015]}\end{array}$ & $\begin{array}{c}-0.045^{* *} \\
{[0.014]}\end{array}$ \\
\hline Constant & $\begin{array}{l}0.179^{* *} \\
{[0.008]}\end{array}$ & & & \\
\hline$N$ & 10445 & 10445 & 10445 & 10445 \\
\hline$R^{2}$ & 0.03 & 0.06 & 0.12 & 0.15 \\
\hline $\begin{array}{l}\text { Year FE } \\
\text { Parish/Constituency FE }\end{array}$ & & $\checkmark$ & $\checkmark$ & $\checkmark$ \\
\hline Year-Constituency FE & & & & $\checkmark$ \\
\hline
\end{tabular}

Notes: Only general elections are included. Outcome is a dummy for casting a split vote. Estimates are conditional on voting. Robust standard errors clustered by voter are reported in brackets. * and ** denote statistical significance at $5 \%$ and $1 \%$ levels, respectively. 

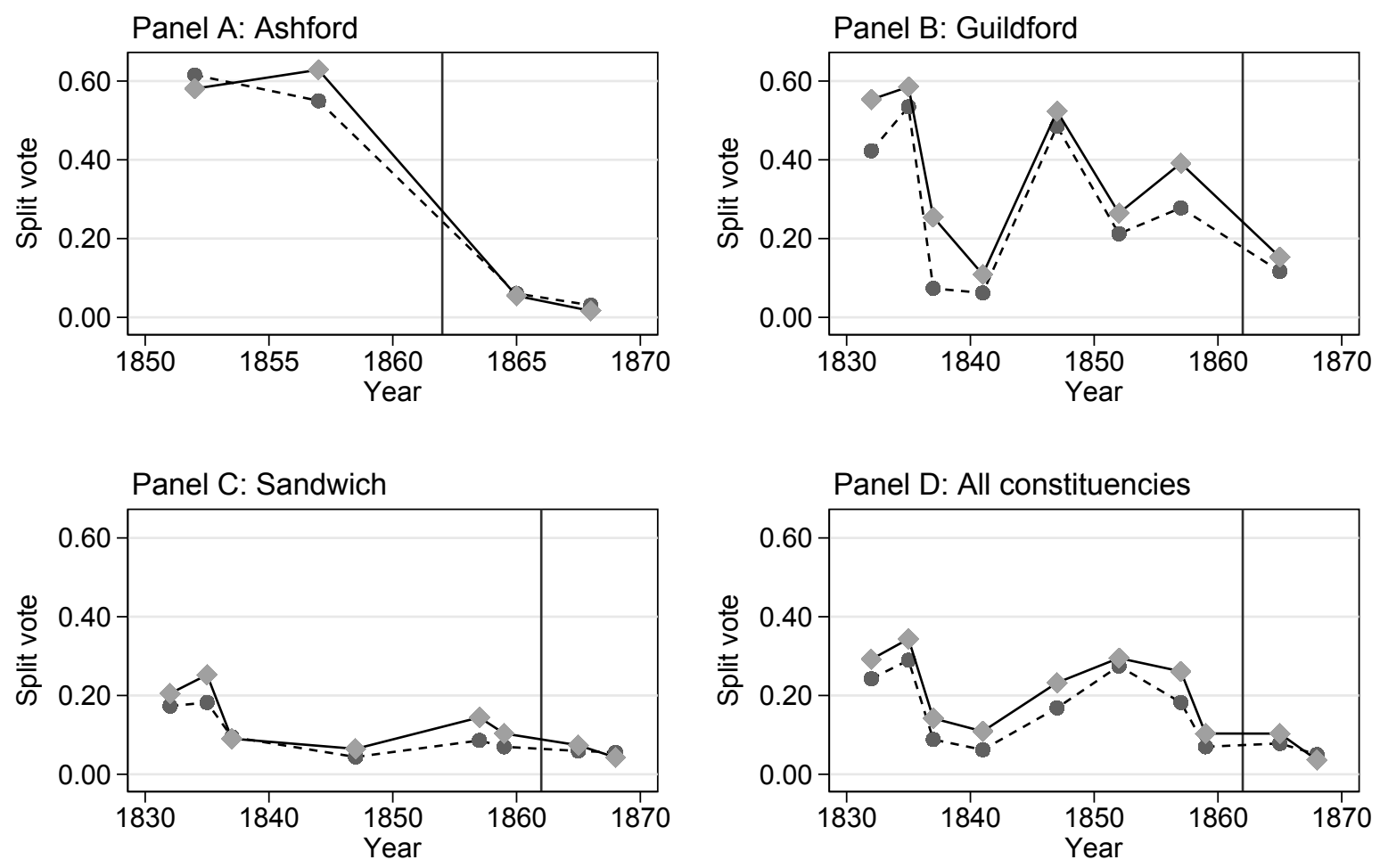

-.--@-.-- Middle class _ - Working class

Figure 2. Split voting by class and election year. 
Table 2. Regression results on voting for the Liberals.

\begin{tabular}{|c|c|c|c|c|}
\hline \multicolumn{4}{|c|}{ Panel A: Ashford } & \\
\hline & $(1)$ & (2) & & \\
\hline 1[Working class] & $\begin{array}{c}0.050 \\
{[0.079]}\end{array}$ & $\begin{array}{c}0.049 \\
{[0.079]}\end{array}$ & & \\
\hline $1[$ Year $\geq 1865]$ & $\begin{array}{l}0.422^{* *} \\
{[0.062]}\end{array}$ & & & \\
\hline 1 [Working class $] \times 1[$ Year $\geq 1865]$ & 0.033 & $\begin{array}{c}0.033 \\
{[0.091]}\end{array}$ & & \\
\hline Constant & $\begin{array}{l}0.253^{* *} \\
{[0.055]}\end{array}$ & & & \\
\hline$N$ & 502 & 502 & & \\
\hline$R^{2}$ & 0.17 & 0.17 & & \\
\hline \multicolumn{5}{|c|}{ Panel B: Guildford } \\
\hline & (3) & (4) & (5) & \\
\hline 1 [Working class] & $\begin{array}{l}-0.049 \\
{[0.026]}\end{array}$ & $\begin{array}{l}-0.037 \\
{[0.026]}\end{array}$ & $\begin{array}{l}-0.035 \\
{[0.026]}\end{array}$ & \\
\hline $1[$ Year $\geq 1865]$ & $\begin{array}{l}-0.001 \\
{[0.035]}\end{array}$ & & & \\
\hline 1 [Working class $] \times 1[$ Year $\geq 1865]$ & $\begin{array}{l}0.138^{* *} \\
{[0.045]}\end{array}$ & $\begin{array}{l}0.126^{* *} \\
{[0.045]}\end{array}$ & $\begin{array}{l}0.119^{* *} \\
{[0.045]}\end{array}$ & \\
\hline Constant & $\begin{array}{l}0.395^{* *} \\
{[0.022]}\end{array}$ & & & \\
\hline$N$ & 3402 & 3402 & 3402 & \\
\hline$R^{2}$ & 0.01 & 0.08 & 0.09 & \\
\hline \multicolumn{5}{|c|}{ Panel C: Sandwich } \\
\hline & (6) & (7) & & \\
\hline 1[Working class] & $\begin{array}{c}-0.072^{* *} \\
{[0.020]}\end{array}$ & $\begin{array}{c}-0.064^{* *} \\
{[0.020]}\end{array}$ & & \\
\hline $1[$ Year $\geq 1865]$ & $\begin{array}{c}0.018 \\
{[0.024]}\end{array}$ & & & \\
\hline 1 [Working class] $\times 1[$ Year $\geq 1865]$ & $\begin{array}{l}0.092^{* *} \\
{[0.032]}\end{array}$ & $\begin{array}{l}0.084^{* *} \\
{[0.032]}\end{array}$ & & \\
\hline Constant & $\begin{array}{l}0.523^{* *} \\
{[0.016]}\end{array}$ & & & \\
\hline$N$ & 6541 & 6541 & & \\
\hline$R^{2}$ & 0.01 & 0.04 & & \\
\hline \multicolumn{5}{|c|}{ Panel D: All constituencies } \\
\hline & (8) & (9) & $(10)$ & $(11)$ \\
\hline 1[Working class] & $\begin{array}{c}-0.062^{* *} \\
{[0.016]}\end{array}$ & $\begin{array}{c}-0.058^{* *} \\
{[0.016]}\end{array}$ & $\begin{array}{c}-0.056^{* *} \\
{[0.016]}\end{array}$ & $\begin{array}{c}-0.053^{* *} \\
{[0.016]}\end{array}$ \\
\hline $1[$ Year $\geq 1865]$ & $\begin{array}{l}0.058^{* *} \\
{[0.019]}\end{array}$ & & & \\
\hline $1[$ Working class $] \times 1[$ Year $\geq 1865]$ & $\begin{array}{l}0.101^{* *} \\
{[0.025]}\end{array}$ & $\begin{array}{l}0.099^{* *} \\
{[0.025]}\end{array}$ & $\begin{array}{l}0.103^{* *} \\
{[0.025]}\end{array}$ & $\begin{array}{l}0.097^{* *} \\
{[0.025]}\end{array}$ \\
\hline Constant & $\begin{array}{l}0.472^{* *} \\
{[0.013]}\end{array}$ & & & \\
\hline$N$ & 10445 & 10445 & 10445 & 10445 \\
\hline$R^{2}$ & 0.01 & 0.03 & 0.05 & 0.08 \\
\hline $\begin{array}{l}\text { Year FE } \\
\text { Parish/Constituency FE }\end{array}$ & & $\checkmark$ & $\checkmark$ & $\checkmark$ \\
\hline Year-Constituency FE & & & & $\checkmark$ \\
\hline
\end{tabular}

Notes: Only general elections are included. Outcome is a dummy for casting a Liberal vote. Estimates are conditional on voting. Robust standard errors clustered by voter are reported in brackets. * and ** denote statistical significance at $5 \%$ and $1 \%$ levels, respectively. 

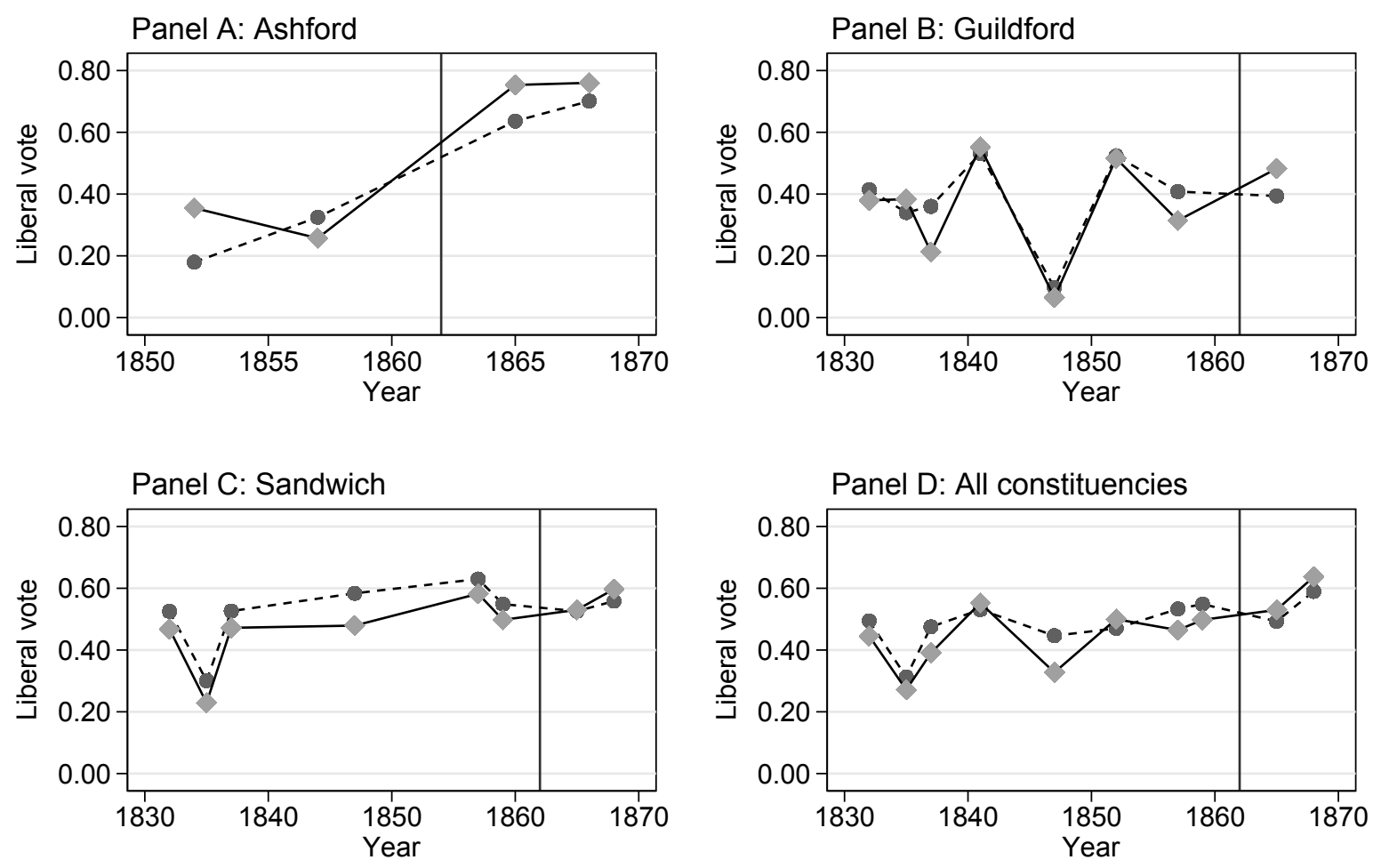

\section{-..-.-.- Middle class —— Working class}

Figure 3. Liberal voting by class and election year. 

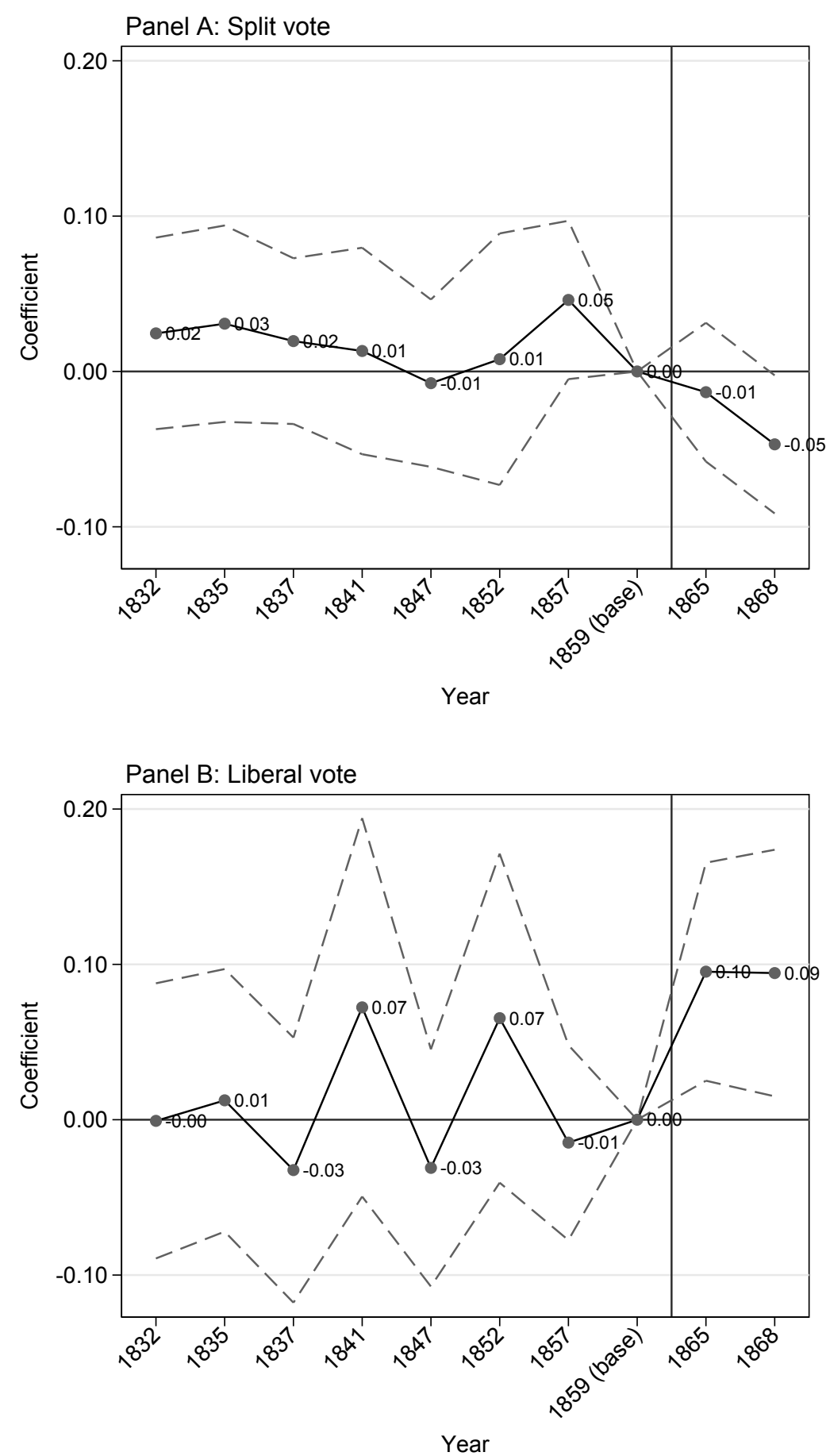

Notes: Figure shows point estimates for each years relative to 1859. Dashed lines are $95 \%$ confidence intervals. Regressions control for election and constituency-election fixed effects.

Figure 4. Coefficients from dynamic difference-in-differences estimation. 


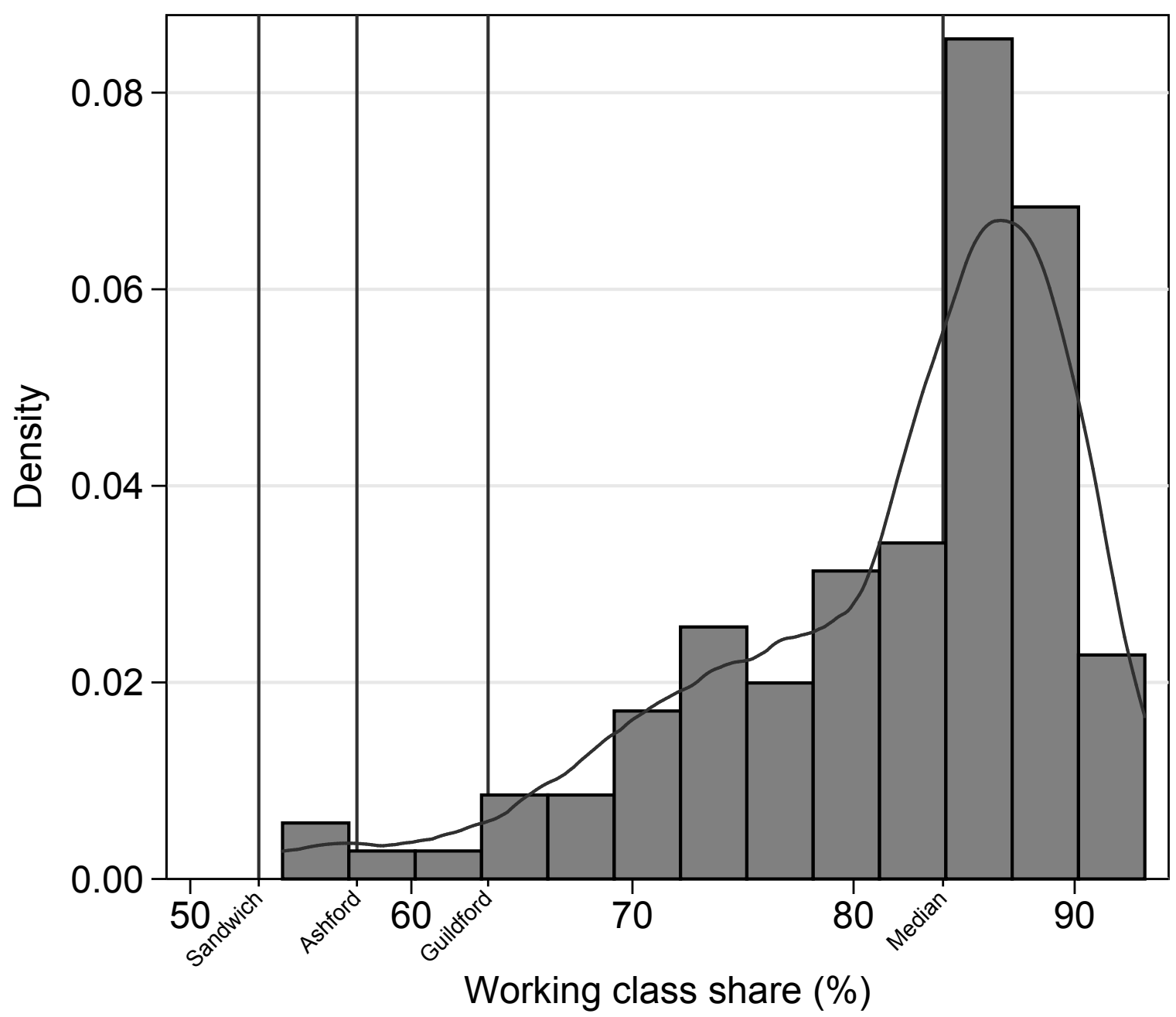

Notes: Vertical lines mark the share of working class population in the census data for Guildford and Kent (that Ashford is part of), or in the poll book data for Sandwich. The share of working class voters is 52\% in Ashford poll book data, and 60\% in Guildford.

Figure 5. Working class share of population in the 1861 census. 


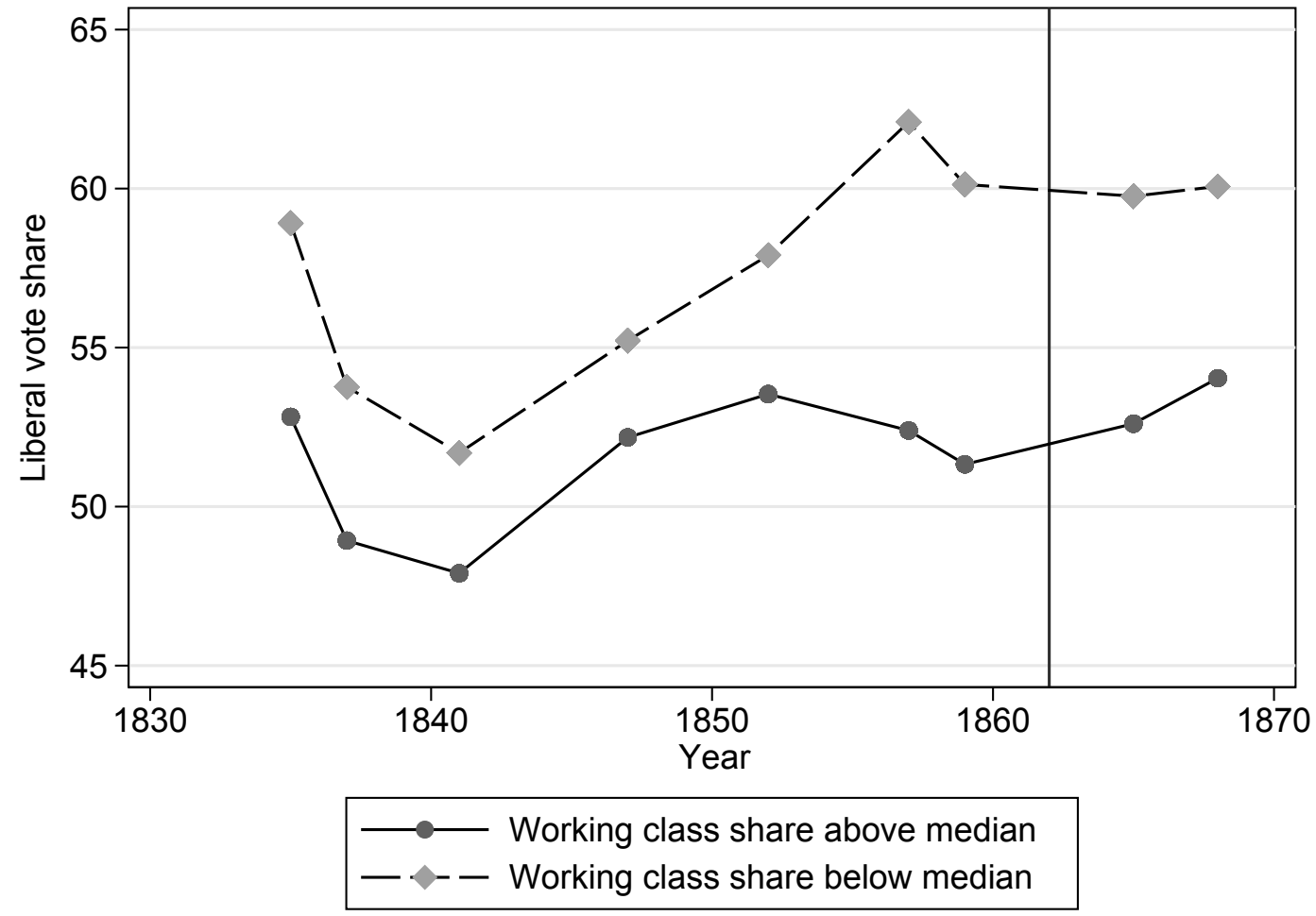

Figure 6. Liberal vote share in constituencies with above and below median share of working class. 